\title{
The break-up of continents and the formation of new ocean basins
}

\author{
By T. A. MINSHULL \\ Southampton Oceanography Centre, European Way, \\ Southampton SO14 3ZH, UK (tmin@soc.soton.ac.uk)
}

Published online 16 October 2002

Rifted continental margins are the product of stretching, thinning and ultimate break-up of a continental plate into smaller fragments, and the rocks lying beneath them store a record of this rifting process. Earth scientists can read this record by careful sampling and with remote geophysical techniques. These experimental studies have been complemented by theoretical analyses of continental extension and associated magmatism. Some rifted margins show evidence for extensive volcanic activity and uplift during rifting; at these margins, the record of the final stages of rifting is removed by erosion and obscured by the thick volcanic cover. Other margins were underwater throughout their formation and showed rather little volcanic activity; here the ongoing deposition of sediment provides a clearer record. During the last decade, vast areas of exhumed mantle rocks have been discovered at such margins between continental and oceanic crust. This observation conflicts with the well-established idea that the mantle melts to produce new crust when it is brought close to the Earth's surface. In contrast to the steeply dipping faults commonly seen in zones of extension within continental interiors, faults with very shallow dips play a key role in the deformation immediately preceding continental break-up. Future progress in the study of continental break-up will depend on studies of pairs of margins which were once joined and on the development of computer models which can handle rigorously the complex transition from distributed continental deformation to sea-floor spreading focused at a mid-ocean ridge.

Keywords: geophysics; plate tectonics; rifting; continental margins

\section{Introduction}

The Earth loses heat from its deep interior largely by slow convective motion of the mantle. The surface expression of this motion is the horizontal movement of relatively rigid plates known as the 'lithosphere'. New lithosphere is formed at mid-ocean ridges, and lithosphere is destroyed by sinking deep into the Earth at subduction zones. The global configuration of plate boundaries is stable on human time-scales, but on time-scales of millions of years, plates can break apart and pairs of plates can become joined.

Evidence for the continuity of geological structures between widely separated continents provided evidence for so-called 'continental drift' long before the development

One contribution of 20 to a Triennial Issue 'Astronomy and Earth science'. 
of the modern theory of plate tectonics. Geophysical exploration and ocean drilling around the submerged edges of continents, known as 'continental margins', led to the concept that continents stretch and thin before finally breaking apart. Rifted continental margins are the product of this stretching and thinning, and the rocks lying beneath them store a record of the rifting process. Earth scientists have learned to read this record by drilling into the rocks at carefully selected locations, by sampling the seabed in areas where crustal rocks are not covered by thick sediments, and by probing the deeper structure with a variety of geophysical techniques. Alongside these experimental studies, theoretical analyses have related the style of deformation of the continental crust to the properties of the rocks within and beneath it. Such approaches have also related the formation of new oceanic crust following break-up of the continent to sea-floor spreading involving the upwelling and melting of the underlying mantle.

The study of rifted margins is becoming of more than academic importance as they become frontier exploration provinces for the oil and gas industry and as nations stake their claims to marine territory with legal arguments based partly on geological criteria. Hydrocarbons are formed by burial and heating, over long periods, of organic matter deposited with sediments. Oil companies are therefore interested in the burial and thermal history of these sediments, which determine the likely volume and composition of such hydrocarbons. Under the United Nations Convention on the Law of the Sea, nations can lay claim to parts of the ocean based on measurements of water depth, sediment thickness and even crustal type.

At rifted margins, continental crust with a typical thickness of $30-40 \mathrm{~km}$ is thinned by a factor of five or more before it finally ruptures. This crustal thinning results in subsidence of the surface and upwelling of the mantle. During upwelling, the temperature of mantle rocks commonly decreases more slowly with pressure than the melting point, so the rocks melt as they decompress. The oceanic crust, typically 6-7 km thick, is formed from the frozen products of such melting. On most margins, the sediment supply is too slow to keep up with the subsidence, and the thinned crust now lies beneath several kilometres of ocean.

Detailed information on the deep structure of margins has come from seismic experiments. These experiments use acoustic waves generated by the release of compressed air from large 'airguns' towed from ships and recorded with hydrophones near the sea surface or on the seabed (e.g. Lonergan \& White 1999). Two seismic techniques are widely used at rifted margins, often simultaneously. In seismic-reflection experiments, seismic signals reflected from boundaries within the Earth are measured and processed to generate an image of the structure, to depths of typically a few tens of kilometres on continental margins. In seismic refraction, or 'wide-angle' seismic experiments, the travel times of the signals are used to infer variations of seismic velocity within the Earth, and hence to define large-scale structure and composition. Modern experiments focused on restricted targets commonly extend these techniques to three dimensions, but the large scale (commonly several hundred kilometres) of rifted margins has generally precluded a three-dimensional approach.

Seismic data from some rifted margins show evidence for extensive volcanic activity and uplift at the start of rifting. At these margins, the uplift results in erosion, which partly removes the geological record of the rifting process. Rift-related structures are further obscured by the thick volcanic cover, which is difficult to penetrate with seismic techniques and difficult to drill through. Other margins, termed here 'magma 


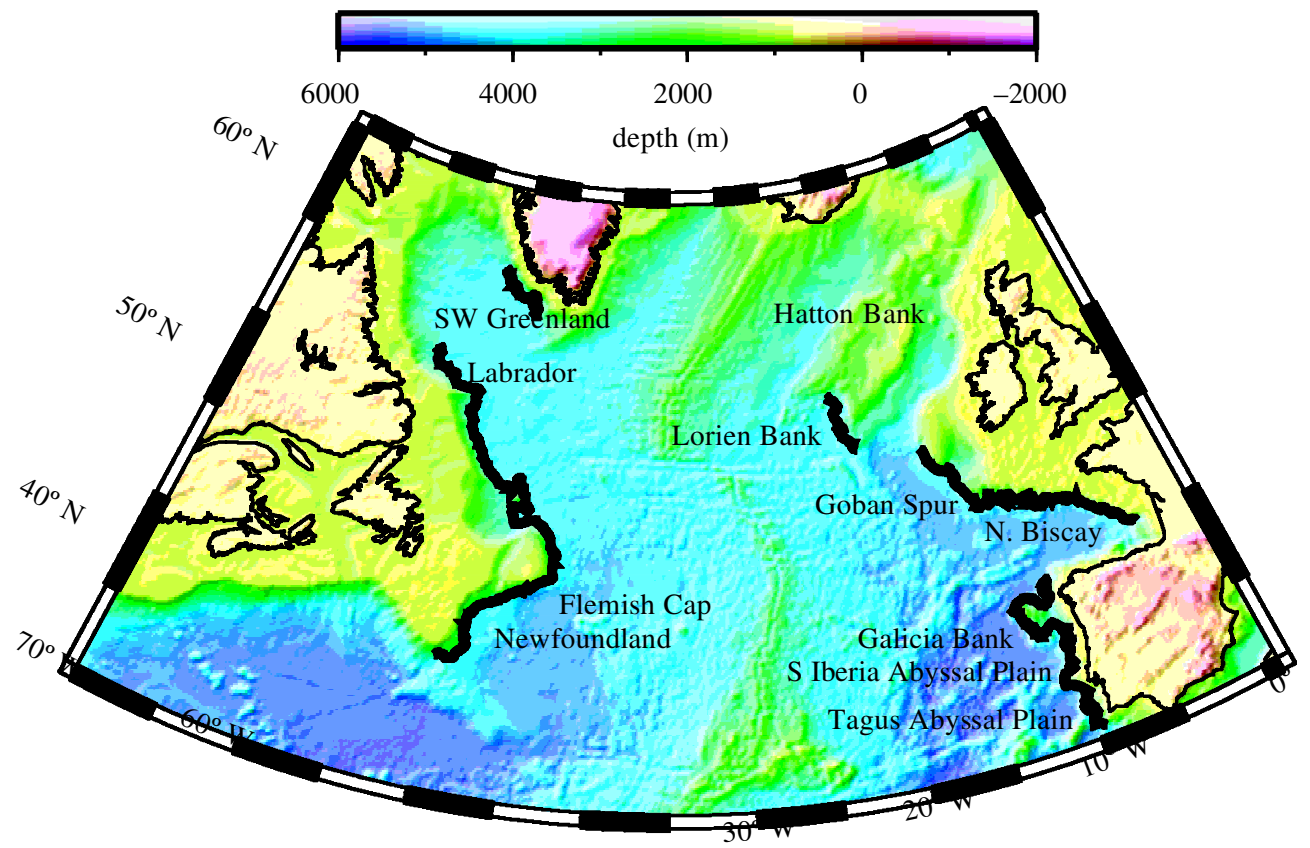

Figure 1. Shaded bathymetry and topography of the North Atlantic Region (Smith \& Sandwell 1997). Labelled thick lines mark the $3000 \mathrm{~m}$ contour, which lies close to the base of the continental slope, at magma-poor rifted margins. The southern rifted margin of the Bay of Biscay has been subducted beneath northern Spain, and the Goban Spur and Lorien Bank margins have been separated by rifting in Rockall Trough. The Hatton Bank volcanic margin (figure 2a) is also labelled.

poor', show evidence of continuous subsidence and had rather little volcanic activity; at these margins these key final stages are more readily documented. This paper focuses mainly on such margins.

\section{Magmatism during continental break-up}

During the last two decades, rifted continental margins around the North Atlantic (figure 1) have been extensively studied using seismic techniques. At many margins, these studies have identified several-kilometre-thick wedges of concave-downward seaward-dipping reflectors beneath the sediment column and above the thinned continental crust. These reflectors were initially interpreted as sedimentary deposits from deltas, but by drilling holes through these deposits, geologists learned that the reflections were generated by lava flows, intercalated with sediments, which acquired their observed shape due to the oceanward increase in subsidence. Wide-angle seismic studies of such margins also revealed up to $15-20 \mathrm{~km}$ thick regions at the base of the stretched crust with seismic velocities of $7.2-7.6 \mathrm{~km} \mathrm{~s}^{-1}$. These velocities are too high for continental crust and too low for the upper mantle, and they are attributed to the presence of magnesium-rich igneous rocks formed by decompression melting of the mantle at the time of continental break-up. The origin of the voluminous igneous 
(a) Hatton Bank

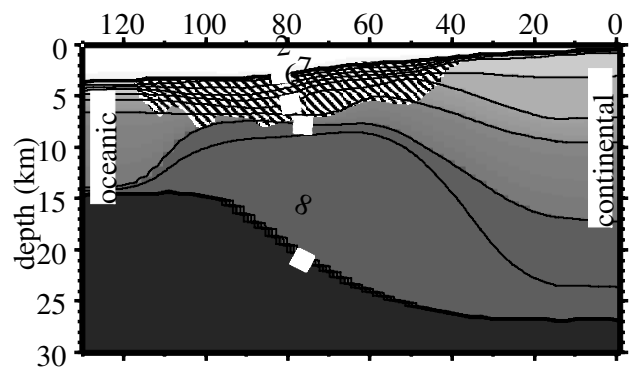

(b) Goban Spur
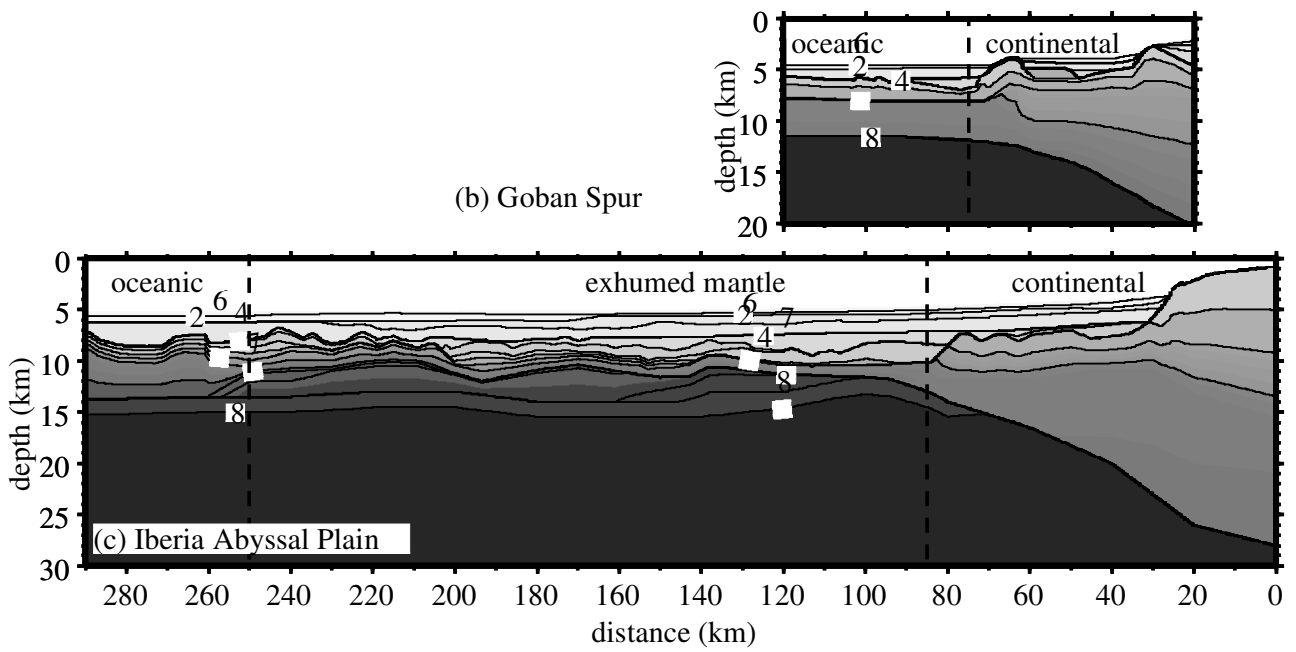

Figure 2. Seismic velocity structures of some North Atlantic rifted margins, plotted at the same scale. In each panel, velocities are contoured at $0.5 \mathrm{~km} \mathrm{~s}^{-1}$ intervals up to $7.0 \mathrm{~km} \mathrm{~s}^{-1}$, and at $0.2 \mathrm{~km} \mathrm{~s}^{-1}$ between 7.0 and $8.0 \mathrm{~km} \mathrm{~s}^{-1}$. (a) Volcanic margin of Hatton Bank (Fowler et al. 1989). Diagonal shading marks regions of seaward-dipping reflectors. The thick region of velocities between 7.2 and $8.0 \mathrm{~km} \mathrm{~s}^{-1}$ is interpreted as magmatic rocks accreted to the base of the crust during rifting. Transition from continental to oceanic crust occurs gradually between ca. 40 and $110 \mathrm{~km}$. (b) Magma-poor Goban Spur margin (Horsefield et al. 1994). The dashed line marks inferred abrupt ocean-continent boundary. (c) West Iberia margin in the southern Iberia Abyssal Plain (Dean et al. 2000). The dashed lines mark the approximate edges of oceanic and of continental crust.

material at such 'volcanic' margins remains controversial. The large volumes suggest that either the mantle beneath these margins was hotter at the time of break-up than the mantle beneath most of the ocean basins or a larger volume of mantle moved up through the depth interval of melting than is normal at mid-ocean ridges. There are a variety of views about the relative importance of these two processes (e.g. White \& McKenzie 1989; Holbrook \& Keleman 1993). Other margins showed very little evidence for magmatic activity until new oceanic crust was formed after the continents broke apart (figure 2). It was inferred that magmatism at these margins was relatively straightforward, with substantial melting of the upwelling mantle only during the final stage of break-up or separation of the continental plate.

Typically a few times every million years, the Earth's magnetic field reverses its polarity. As new oceanic crust forms, magnetic minerals in the crust align themselves 
with the magnetic field, so the geologically frequent polarity reversals result in the formation of a series of 'stripes' of crust of alternating magnetic polarity. These magnetic stripes have been comprehensively mapped in the North Atlantic (figure 3), and in the absence of more detailed information they provide a straightforward means of identifying oceanic crust. A long-standing observation from many magma-poor margins in the North Atlantic is that the first magnetic anomaly stripe is often tens or even hundreds of kilometres from the foot of the continental slope. The absence of magnetic stripes close to margins may in some cases be attributed to continental break-up between 120 and 84 million years ago, when the Earth's magnetic field underwent no stable polarity reversals, or before ca. 155 million years ago, when frequent reversals of a weak magnetic field resulted in weak to undetectable anomaly lineations. However, in other cases an alternative explanation must be sought. Over the last decade, the exploration of magma-poor margins has extended out into these weakly magnetic abyssal plain regions. It is here that the process of transition from continental stretching to oceanic sea-floor spreading is recorded. Such regions have commonly been called 'transition zones', but this term may be misleading, since their structure is not transitional between oceanic and continental crust, as is observed at volcanic margins, but rather is distinct from both.

Intense surveying and sampling of one such weakly magnetic region, in the southern Iberia Abyssal Plain west of the Iberian peninsula (figure 1), has led to the unexpected discovery that rocks from the mantle were exposed at the sea floor at the time of rifting in an area tens to hundreds of kilometres across (Whitmarsh et al. 2001). This zone of exhumed mantle is characterized by anomalously deep basement (the top of the crystalline crust) with generally low relief and by a seismic velocity structure that is different from both oceanic crust and stretched continental crust. Seismic velocities rise steeply to $c a .7 \mathrm{~km} \mathrm{~s}^{-1}$ only $2 \mathrm{~km}$ beneath the basement, and then increase gradually to normal mantle values of $c a .8 \mathrm{~km} \mathrm{~s}^{-1} c a .6 \mathrm{~km}$ beneath the basement (figure 2c), without the abrupt discontinuity which normally marks the base of the crust (as in figure $2 a, b$ ). This pattern may be explained by a progressive reduction in the degree of alteration of mantle rocks with depth as chemical reactions with sea water become more limited. In contrast with oceanic crust, where strongly magnetic rocks appear to be concentrated primarily in the upper $2 \mathrm{~km}$, and continental crust, which is normally only weakly magnetic, the zone has weak linear magnetic anomalies that appear to originate several kilometres beneath the basement. Drilling in the same region has found no evidence for magmatism at the time of rifting, and has reached altered mantle rocks beneath the sediments at several locations, confirming the conclusions drawn from geophysical data. The above observations and interpretations apply to one small region of the west Iberia margin. However, a series of margin-parallel basement highs extend northward from the southern Iberia Abyssal Plain to a point where the basement outcrops at the seabed off Galicia Bank (figure 1). Here, sampling by submersible and by dredging has also recovered mantle rocks, suggesting that the zone of exhumed mantle extends several hundred kilometres along the margin. Geophysical studies of other North Atlantic margins, such as the Labrador-southwest Greenland pair (figure 1), have also inferred the presence of such a zone (e.g. Louden \& Chian 1999).

In parallel with the above developments in the study of rifted continental margins, an intense international effort has focused on the process of formation of new oceanic crust at mid-ocean ridges. One product of these efforts is a relatively clear under- 


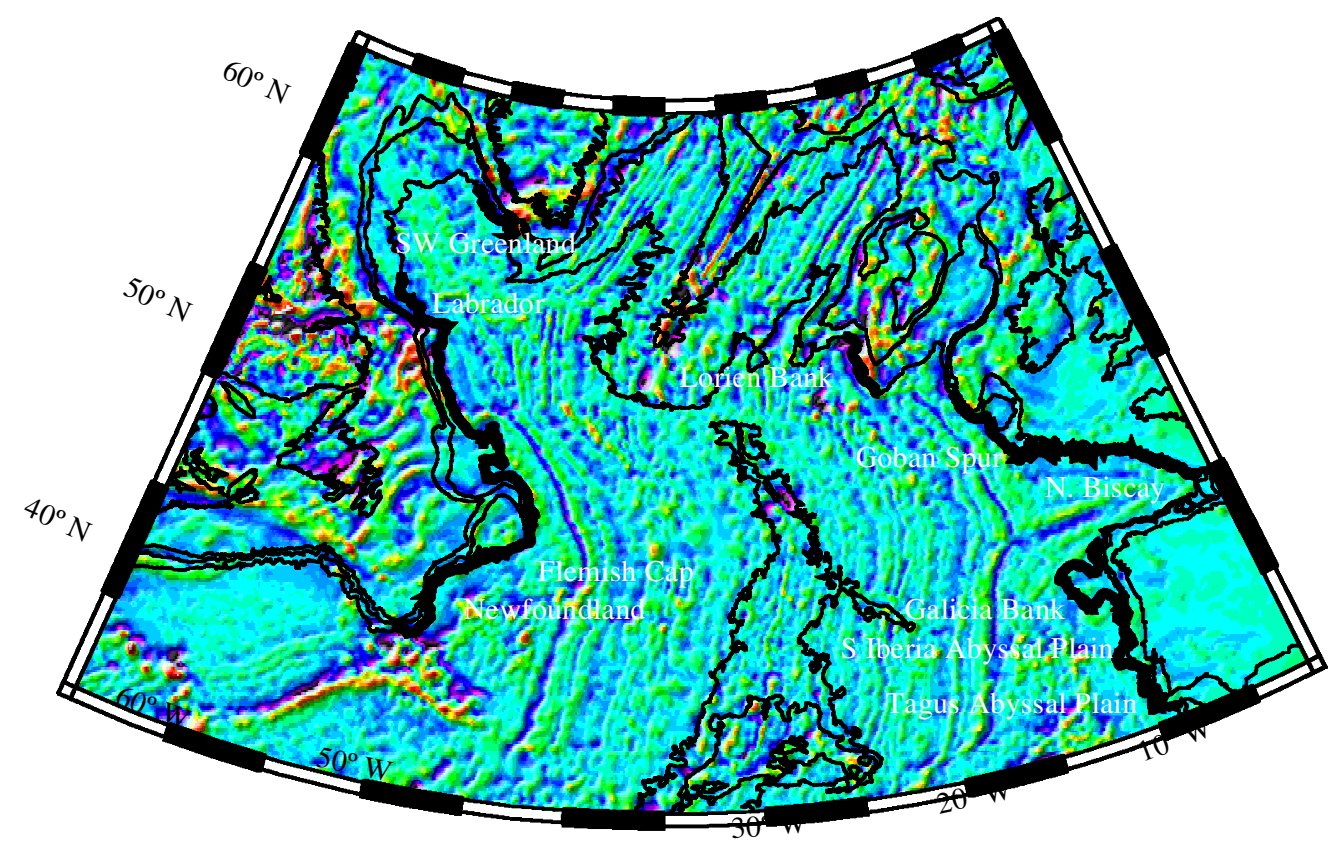

Figure 3. Magnetic anomalies of the North Atlantic (Verhoef et al. 1996). Thin black lines mark coastlines and the 1000, 2000 and $3000 \mathrm{~m}$ contours. Thick black lines mark magma-poor margins as in figure 1. Linear magnetic anomalies appear close to the margins northwest of Scotland and southeast of Greenland, whereas large regions without such anomalies are present in the Bay of Biscay, west of Iberia and east of Newfoundland in the Labrador Sea.

standing of how the mantle melts at mid-ocean ridges and forms new oceanic crust. Computer models of the thermal structure of mid-ocean ridges, based on the separation of relatively rigid plates above a slowly convecting layer called the 'asthenosphere', combined with laboratory-derived knowledge of the melting behaviour of mantle rocks, have successfully matched the volume and even the composition of oceanic crust formed at a variety of spreading rates.

These models have also been successfully applied to volcanic rifted margins, though in a variety of ways resulting in conflicting interpretations. However, they appear to break down when applied to the west Iberia margin (figure 4). In the zone of exhumed mantle, magnetic measurements indicate that the uppermost $2 \mathrm{~km}$ of the crystalline crust does not consist of the melt products; at $2-6 \mathrm{~km}$ depth below basement the seismic velocities are too high for magmatic rocks to form more than ca.50\% of the volume, and beyond a depth of $c a .6 \mathrm{~km}$ the velocity is that of unaltered mantle. Therefore, the mean thickness of rocks formed by mantle melting at the time of rifting is unlikely to be more than $c a .2 \mathrm{~km}$. If we assume that the absence of continental crust means that the preexisting lithosphere has been thinned to negligible thickness, and that the extension rate is similar to that during the subsequent period of seafloor spreading, the predicted melt thickness is $c a .4 \mathrm{~km}$ (figure 4). The absence of voluminous magmatic rocks may be attributed to some special circumstance such as unusually low mantle temperatures at the time of rifting, but such arguments 

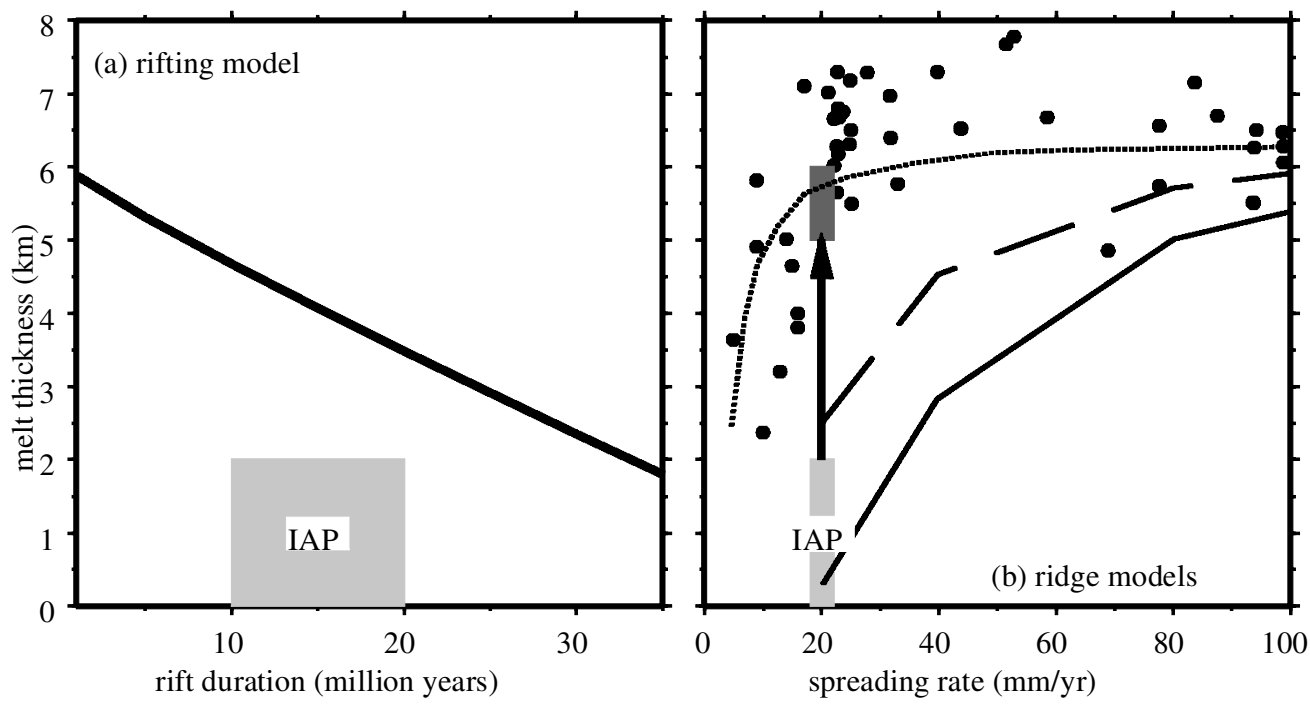

Figure 4. (a) The line marks the predicted melt thickness as a function of rift duration for lithospheric stretching by a factor of 50 (beyond which further stretching generates negligible melt volumes) over normal-temperature mantle for a model that takes account of heat loss by conduction. The shaded box marks the estimated melt thickness in the zone of exhumed mantle in the southern Iberia Abyssal Plain (IAP) and inferred rift duration from drilling and geophysical observations. (b) The lines mark the melt thickness as a function of spreading rate from models of melt generation at mid-ocean ridges: solid line, constant mantle viscosity; dashed line, temperature-dependent viscosity; dotted line, a lithosphere that thickens more steeply away from the ridge axis at slow spreading rates than would be predicted from temperature variations. The dots mark seismic measurements of oceanic crustal thickness as a function of spreading rate, and shaded regions mark the inferred melt thickness in the zone of exhumed mantle of figure $2 c$, and the first-formed oceanic crust of figure $2 c$, with the arrow indicating evolution over time (modified from Minshull et al. (2001)).

break down if, as appears to be the case, zones of exhumed mantle are widespread at magma-poor margins.

A factor that has only recently begun to be addressed in computer models of magma-poor rifted margins is that the thermal and viscosity structure of the mantle immediately after continental break-up is very different from that of a mid-ocean ridge where spreading has continued for many millions of years. The volume of melt generated from the upwelling mantle is controlled primarily by the upwelling rate, which in turn is controlled by the plate-separation (spreading) rate. Faster upwelling leads to greater melt volumes, but these volumes are spread over a greater surface area created by plate separation, so if the upwelling is sufficiently rapid that little heat is lost, crustal thickness changes little with spreading rate. However, if upwelling is slower, significant heat is lost by conduction and the net effect is the formation of thinner crust. A compensating effect is that the slope of the base of the lithosphere becomes steeper at slower spreading rates, so that the ratio between upwelling rate and spreading rate becomes larger. Computer models have shown that if the mantle viscosity structure (and hence the shape of the base of the lithosphere) is determined only by temperature and the upwelling is a purely passive response to plate sepa- 


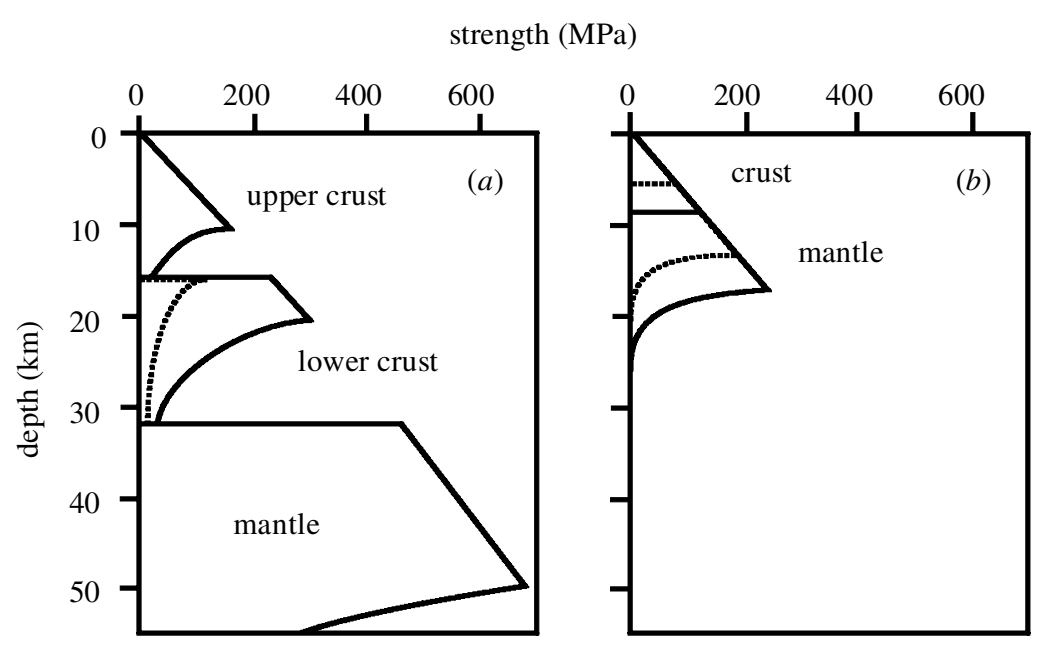

Figure 5. Strength profiles for the continental lithosphere at different stages of extension (modified from Perez-Gussinye \& Reston (2001)). Profiles assume that the crust is initially $32 \mathrm{~km}$ thick, the temperature at the base of the crust is $515{ }^{\circ} \mathrm{C}$, the upper crust deforms like wet quartz, and the mantle deforms like dry olivine. Solid and dashed profiles indicate a range of possible behaviours for the lower crust. Brittle strength increases linearly with depth, while in the lower crust strength decays rapidly with depth due to increasing temperatures. (a) Initial conditions. (b) Strength profile when the whole crust is brittle, which occurs when the crust has stretched by a factor of 3.6 for the solid profile and 6.1 for the dashed profile.

ration, this compensating effect is small and crustal thickness decreases steadily as spreading rate decreases (figure 4).

Results from seismic experiments show that crustal thickness in fact changes little with spreading rate, except at very slow rates (less than $c a .20 \mathrm{~mm} \mathrm{yr}^{-1}$ ). These observations can be explained only if upwelling rates are faster at slow spreading rates than predicted by the models discussed above. Recently, it has been shown that the removal of water from the mantle during melting results in a profound increase in its viscosity (Hirth \& Kohlstedt 1996), so that the onset of melting itself causes the base of the lithosphere to steepen and upwelling rates to increase. Immediately after continental break-up, little melting occurs and the space generated by plate separation is filled by slow upwelling over a broad area. Perhaps at magma-poor margins the formation of oceanic crust of normal thickness is delayed until further melting results in a narrowing of the upwelling region.

\section{Deformation during continental break-up}

At the very slow rates of geological processes, rocks are brittle if they are cold, but they can flow if they are warm in the same way that glass flows to the bottom of ancient window panes. Despite the development of sophisticated computer and analogue models, the consequences of such flow for large-scale extension have remained controversial. Computer models have to make many idealizing assumptions, and analogue models, which can elegantly illustrate the consequences of particular flow laws, are limited by an inability to reproduce temperature-dependent changes in the flow behaviour during extension. Neither has an extensive database of field observations 


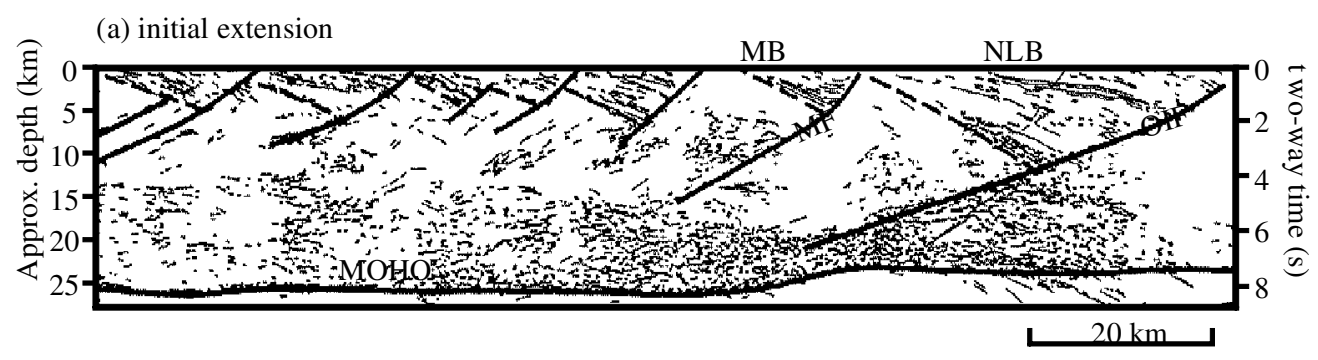

(b) final breakup

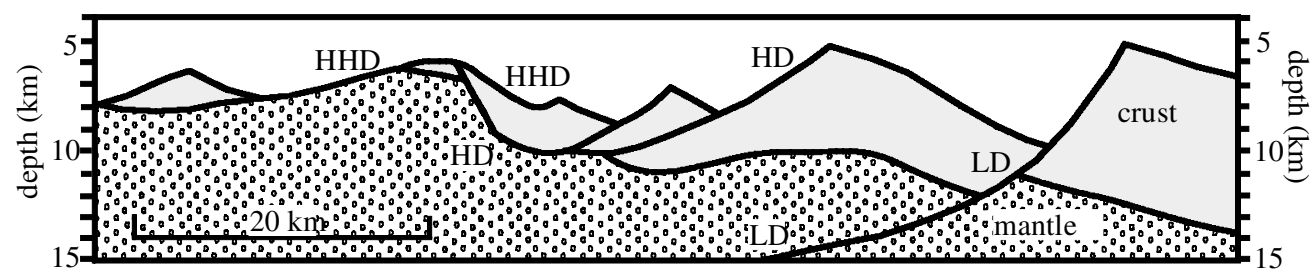

Figure 6. Seismic images of lithospheric extension. (a) A seismic-reflection profile from the continental shelf north of Scotland (modified from Flack \& Warner (1990)). The depth-scale assumes a seismic velocity of $6 \mathrm{~km} \mathrm{~s}^{-1}$, which is typical for continental crust, and there is no vertical exaggeration for this seismic velocity. MB is the Minch Basin and NLB is the North Lewis Basin; MF and OIF (Outer Isles Fault) are faults bounding these basins. The Moho is a seismic boundary marking the base of the crust. Faults are steep near the surface; some disappear in the mid crust, while others extend into the lower crust. Fault shapes at depth are distorted by lateral variations in seismic velocity in the upper crust. (b) An interpretation of a seismic-reflection profile from the final stages of continental break-up west of Iberia (modified from Whitmarsh et al. (2000) and Manatschal et al. (2001)). LD and HD are detachment faults which flatten at depth; HHD is a 'rolling-hinge' fault.

resolved the controversy. A key question is the extent to which extension in the upper crust is decoupled from deeper deformation by a weak layer in the lower crust. Such a weak layer is expected on the basis of extrapolation of flow laws based on short-time-scale laboratory measurements to geological time-scales (figure 5). These laws predict that, for typical temperatures at the base of the crust of $c a .500{ }^{\circ} \mathrm{C}$, the upper crust and uppermost mantle are brittle but the lower crust deforms by flow. The validity of such extrapolations is unclear, and further uncertainty comes from the poorly known and probably variable composition of the lower continental crust.

A consequence of a weak lower crust is that thinning due to extension in the upper crust will not be matched by an equal degree of thinning in the lower crust and mantle lithosphere because of horizontal flow in the lower crust driven by density contrasts. Further consequences are that steeply dipping faults in the upper crust, detected by seismic experiments (figure 6), are expected to flatten at depth, and that few earthquakes are expected in the lower crust. Such characteristics are observed in some actively extending regions, such as the Basin and Range province of the western US, where significant stretching of the upper crust is not matched by corresponding changes in topography or crustal thickness. However, evidence for a strong lower crust comes from sedimentary basins such as the North Sea, where uniform extension is observed throughout the crust; from the observation that earthquakes in extensional zones occur more often on steeply dipping faults; and from the presence 
of a significant number of earthquakes in the lower crust in some areas of active extension (e.g. Maggi et al. 2000).

Whether or not a weak layer is present in the lower crust, flow laws predict that once the crust has been extended by a factor of 3-5, the entire crust becomes brittle (figure 5). Once this happens, the behaviour should be much more predictable, since the strength of rocks varies little with composition when they are cool enough to be brittle. However, even in the absence of magmatism, a further complication arises in the last stages of continental break-up. If the mantle temperature is not unusually high and the rifting is not unusually rapid, by this time the crust lies beneath $c a .2 \mathrm{~km}$ of water and the temperature at the base of the crust has cooled significantly below $500{ }^{\circ} \mathrm{C}$. Sea water penetrates the entire crust through faults and fissures and comes into contact with mantle rocks. Olivine, the predominant mineral in the mantle, reacts with water at temperatures below $500{ }^{\circ} \mathrm{C}$ to produce a very weak mineral called serpentine. Laboratory studies have shown that once 10-15\% serpentine is present, the strength of mantle rocks drops abruptly, so we might expect to see evidence for a weak layer at the top of the mantle under these conditions.

Consistent with these ideas, seismic studies of magma-poor rifted margins have imaged faults that flatten significantly with depth and merge with 'detachment' faults with very shallow dips. These faults play a key role in the deformation immediately preceding continental break-up (figure 6). In the region of deep drilling west of Iberia, restoration of motion along such faults results in a crustal section only $7 \mathrm{~km}$ thick. Structures resulting from the extension which reduced the crustal thickness to $7 \mathrm{~km}$ from the initial thickness of $c a .30 \mathrm{~km}$ are not resolved (Whitmarsh et al. 2001). Seismic observations of such regions rarely resolve basement structures less than a few hundred metres across. Observations from fragments of rifted margins which have been lifted onshore by mountain-building processes, such as in the eastern Swiss Alps, where structures can be mapped on scales from a few centimetres to a few kilometres, fill in an important gap in horizontal scale between seismic and borehole observations. Similar styles of faulting have been observed within these fragments (Whitmarsh et al. 2001).

A puzzling observation from drilling off west Iberia was that, where mantle rocks formed the basement, they were generally overlain by a layer of fractured rocks called breccia. Also, in the Swiss Alps, large near-horizontal expanses of exposed mantle rocks appear to represent fault surfaces, and this observation has led to the suggestion that regions of flat basement observed west of Iberia may also represent fault surfaces (figure 6). Computer models have shown that if faults weaken as motion along them proceeds and they form by extension of a relatively thin brittle layer, faults with an initial steep dip may rotate close to horizontal and acquire almost unlimited offset at these low angles (Lavier et al. 1999). These conditions are satisfied in the last stages of continental break-up, where a thin brittle layer overlies hot mantle rocks and faults are lubricated by serpentine minerals. Fault rotation allows large expanses of mantle rocks to be exposed with very low relief, giving a neat match with a variety of observations.

\section{The future}

Advances in our understanding of continental break-up have been driven by a combination of computer and analogue modelling, laboratory measurements, geophysical 
studies at sea and drilling into rocks and sediments at continental margins. Future progress will depend on a similar combination of techniques. The transition from continental rifting to sea-floor spreading provides a particularly challenging problem for computer models. To date such models have often either considered continental deformation in isolation, without addressing the extraction of melt from the mantle, or focused on melt extraction in response to a predefined rift evolution. Few models have considered the effect on the flow properties of the lithosphere of melt extraction and its subsequent addition to the crust. Close to the time of break-up, the highly nonlinear effect of the penetration of water into the mantle must also be considered. Many of these issues have been addressed by researchers studying mid-ocean ridges. Significant progress may come from the application of some of the approaches taken at ridges to continental break-up, where the evolution of the large-scale structure over time adds an extra complication.

The low-angle faulting processes described above can be expected to lead to significant asymmetries in structure. Therefore, it is likely that significant advances will be made from studying pairs of margins which have rifted away from each other. Regions of present-day continental break-up are obvious targets: the Gulf of California, the Woodlark Basin east of Papua New Guinea, the western Gulf of Aden and the northern Red Sea. Unfortunately, rifting in the Gulf of California is very oblique; the fragment of crust which is rifting in the Woodlark Basin is unlikely to represent typical continental crust; the Gulf of Aden is affected by nearby hot mantle; and thick salt deposits in the northern Red Sea make seismic imaging difficult. Hence, we must also look at pairs of ancient rifted margins.

Once a mature ocean basin has formed, it becomes relatively difficult to reconstruct a pair of rifted margins in their original location. Such reconstructions rely on mapping systematic offsets in magnetic lineations ('fracture zones'), and corresponding lineations in the topography of the ocean floor, which can be detected by gravity measurements even when they are covered by a blanket of sediment. Close to the margins of the North Atlantic (figures 1 and 3), these lineations are largely absent. The 'other half' of the west Iberia margin now lies east of Newfoundland. There, an extensive geophysical survey will be followed by deep drilling in 2003 at a site inferred to have been close to the borehole sites off Iberia at the time of continental break-up. This first comprehensive study of such a margin pair will undoubtedly add significantly to our understanding of the break-up process. Further progress may be made by studying margin pairs where fracture-zone lineations allow a more accurate reconstruction than is possible in the North Atlantic, or developing new methods for determining the direction of plate separation in the absence of such lineations.

An important controlling parameter in continental break-up is the rate of plate separation. At the North Atlantic margins studied in detail to date, this rate is uniformly low: typically ca. $20 \mathrm{~mm} \mathrm{yr}^{-1}$. At higher extension rates, the melting model curves of figure $4 b$ converge, so the transition to normal-thickness oceanic crust after continental break-up is expected to be much more rapid. Conductive cooling should be less significant, so lubrication of faults by serpentinization may be less common and the resulting margin structures therefore more symmetrical. Studies of margins elsewhere in the world, formed at a variety of spreading rates, are needed to test these ideas. To date, studies of rifted margins have focused primarily on large-scale structure: the length-scale of crustal thinning, the location of the seaward limit of continental crust, the landward limit of oceanic crust, and the nature of any region 
between them. A further strand of future work will be the interpretation of moredetailed structures in seismic-reflection profiles across margins, based on comparison of structures mapped on land or sampled by deep drilling.

I thank The Royal Society for support through a University Research Fellowship and the Natural Environment Research Council for supporting geophysical work west of Iberia. Many of the ideas in this paper were developed during a long collaboration with R. B. Whitmarsh.

\section{References}

Dean, S. M., Minshull, T. A., Whitmarsh, R. B. \& Louden, K. E. 2000 Deep structure of the ocean-continent transition in the southern Iberia Abyssal Plain from seismic refraction profiles. II. The IAM-9 transect at $40^{\circ} 20^{\prime}$ N. J. Geophys. Res. 105, 5859-5886.

Flack, C. \& Warner, M. 1990 Three-dimensional mapping of seismic reflections from the crust and upper mantle, northwest of Scotland. Tectonophysics 173, 469-481.

Fowler, S. R., White, R. S., Spence, G. D. \& Westbrook, G. K. 1989 The Hatton Bank continental margin. II. Deep structure from two-ship expending spread profiles. Geophys. J. Int. 96, 295309.

Hirth, G. \& Kohlstedt, D. L. 1996 Water in the oceanic upper mantle: implications for rheology, melt extraction and the evolution of the lithosphere. Earth Planet. Sci. Lett. 144, 93-108.

Holbrook, W. S. \& Keleman, P. B. 1993 Large igneous province on the US Atlantic margin and implications for magmatism during continental breakup. Nature 364, 433-436.

Horsefield, S. J., Whitmarsh, R. B., White, R. S. \& Sibuet, J.-C. 1994 Crustal structure of the Goban Spur rifted continental margin, NE Atlantic. Geophys. J. Int. 119, 1-19.

Lavier, L. L., Buck, W. R. \& Poliakov, A. N. B. 1999 Self-consistent rolling-hinge model for the evolution of large-offset low-angle normal faults. Geology 27, 1127-1130.

Lonergan, L. \& White, N. 1999 Three-dimensional seismic imaging of a dynamic Earth. Phil. Trans. R. Soc. Lond. A 357, 3359-3375.

Louden, K. E. \& Chian, D. 1999 The deep structure of non-volcanic rifted continental margins. Phil. Trans. R. Soc. Lond. A 357, 767-804.

Maggi, A., Jackson, J. A., McKenzie, D. \& Priestley, K. 2000 Earthquake focal depths, effective elastic thickness and the strength of the continental lithosphere. Geology 28, 495-498.

Manatschal, G., Froitzheim, N., Rubenach, M. \& Turrin, B. D. 2001 The role of detachment faulting in the formation of an ocean-continent transition: insights from the Iberia Abyssal Plain. In Non-volcanic rifting of continental margins: a comparison of evidence from land and sea (ed. R. C. Wilson, R. B. Whitmarsh, B. Taylor \& N. Froitzheim), vol. 187, pp. 405-528. Geological Society London.

Minshull, T. A., Dean, S. M., White, R. S. \& Whitmarsh, R. B. 2001 Anomalous melt production after continental breakup in the southern Iberia Abyssal Plain. In Non-volcanic rifting of continental margins: a comparison of evidence from land and sea (ed. R. C. Wilson, R. B. Whitmarsh, B. Taylor \& N. Froitzheim), vol. 187, pp. 537-550. Geological Society London.

Perez-Gussinye, M. \& Reston, T. J. 2001 Rheological evolution during extension at nonvolcanic rifted margins: onset of serpentinization and development of detachments leading to continental breakup. J. Geophys. Res. 106, 3961-3975.

Smith, D. T. \& Sandwell, W. H. F. 1997 Global seafloor topography from satellite altimetry and ship depth soundings. Science 277, 1956-1962.

Verhoef, J., Roest, W. R., MacNab, R., Arkani Hamed, J. \& Members of the Working Group 1996 Magnetic anomalies of the Arctic and North Atlantic Oceans and adjacent land areas. Geological Survey Canada Open File 3125a.

White, R. S. \& McKenzie, D. 1989 Magmatism at rift zones: the generation of volcanic continental margins and flood basalts. J. Geophys. Res. 94, 7685-7730.

Phil. Trans. R. Soc. Lond. A (2002) 
Whitmarsh, R. B., Dean, S. M., Minshull, T. A. \& Tomkins, M. 2000 Tectonic implications of exposure of lower continental crust beneath the Iberia Abyssal Plain, Northeast Atlantic Ocean: geophysical evidence. Tectonics 19, 919-942.

Whitmarsh, R. B., Manatschal, G. \& Minshull, T. A. 2001 Evolution of magma-poor continental margins from final rifting to seafloor spreading. Nature 413, 150-154. 


\section{AUTHOR PROFILE}

\section{Tim Minshull}

Tim Minshull has a first class honours degree in physics from the University of Cambridge. After completing an MSc in geophysics at Durham, he returned to Cambridge to complete a $\mathrm{PhD}$ in marine geophysics in 1990 . After a short period as a lecturer in geophysics in Birmingham, he returned to Cambridge in 1991, where he spent a further eight years first as a research associate and then as a Royal Society University Research Fellow. In 1999 he moved to Southampton Oceanography Centre, where he joined the academic staff as a Reader in 2002. Aged 39, his main research interests are the deep structure of rifted continental margins and methane hydrates in marine sediments.

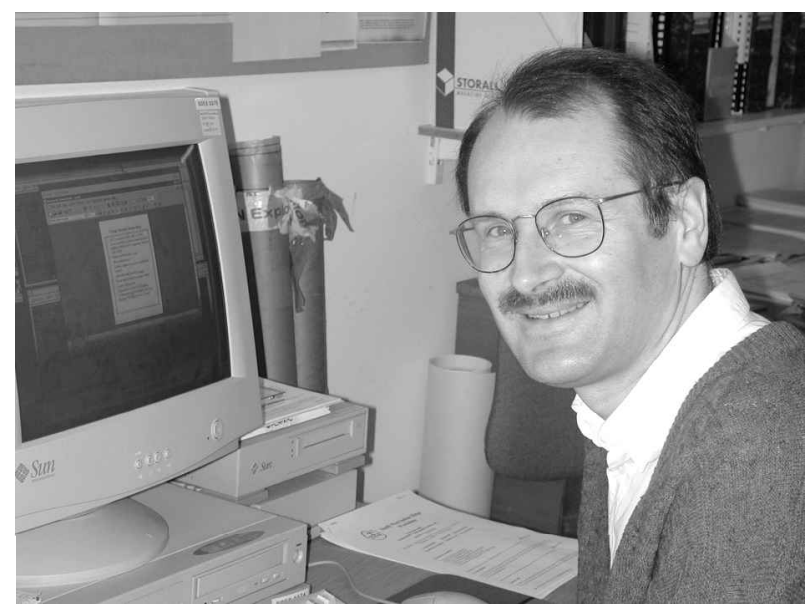

